\title{
Reversal of osteopenia with diet in adult coeliac disease
}

\author{
T Valdimarsson, O Löfman, G Toss, M Ström
}

\begin{abstract}
To evaluate the effects of a gluten free diet on bone mineral density in untreated adult patients with coeliac disease, 63 patients (17-79 years, 35 women) were examined at diagnosis and after one year taking a gluten free diet. Bone mineral density was measured in the forearm using single photo absorptiometry and in the lumbar spine, femoral neck, and trochanter using dual energy $x$ ray absorptiometry. The values for each patient were compared with those of 25 healthy controls, matched for sex, age, and menopausal state. Before being given a gluten free diet bone mineral density in the total group was reduced at all sites $(p<0 \cdot 001)$. Age adjusted bone mineral density was inversely correlated with age. During the first year taking a gluten free diet bone mineral density increased at all sites $(p<0.01)$. This was seen in patients of all ages and in patients who were without symptoms of malabsorption (weight loss or diarrhoea) before treatment. Low bone mineral density in patients with untreated coeliac disease increases rapidly when treatment with a gluten free diet is followed. These findings emphasise the importance of early diagnosis and treatment in all patients with coeliac disease. (Gut 1996; 38: 322-327)
\end{abstract}

Keywords: bone mineral density, coeliac disease, gluten free diet, osteomalacia, osteopenia, osteoporosis, parathyroid hormone, vitamin D.

Patients with coeliac disease often have osteopenia, osteomalacia or osteoporosis. ${ }^{1-6}$ Coeliac disease has been found in at least 3\% of patients referred for osteoporosis. ${ }^{7}$ Recent studies have shown reduced bone mineral density (BMD) in adults with untreated coeliac disease. ${ }^{8-10}$ The effect on the bone mass of dietary treatment of coeliac disease is less well known. One prospective study did not show improvement in BMD after one year taking a gluten free diet. ${ }^{8}$ We have previously shown that the BMD was normal in patients with coeliac disease who adhered to gluten free diet and had normal small bowel mucosa for at least four years follow up. ${ }^{11}$ The aim of this prospective study was to investigate the occurrence of low BMD in patients with untreated coeliac disease and in particular the effect of gluten free diet in patients of different ages.

\section{Methods}

\section{Patients and controls}

From November 1989 to December 1993, we examined 65 consecutive patients with newly diagnosed coeliac disease. Inclusion criteria were clinical suspicion of coeliac disease, such as diarrhoea, weight loss, dyspepsia or biochemical abnormalities. All patients had villous atrophy in the proximal small bowel of gade III or IV on the basis of Alexander's classification. ${ }^{12}$ Exclusion criteria were the presence of other disease(s) known to affect the bone mineral density. One patient was excluded because of a history of hypercalcaemic hyperparathyroidism and one was unwilling to have bone density measurement performed at the completion of one year of the recommended diet. We thus included 63 patients, median age 53.5 years, range $17-79$, 35 women. Seven patients also had dermatitis herpetiformis. After one year of a gluten free diet we saw histologically confirmed improvement in the mucosal abnormalities in 58 patients, two were unwilling to undergo second biopsy and three patients still had severe mucosal atrophy (grade III-IV). All but one of these patients claimed adherence to a strict gluten free diet. Thirteen patients who had low ionised serum calcium $(\leqslant 1 \cdot 18$ $\mathrm{mmol} / \mathrm{l}$ ) or low dietary calcium intake, or both,
Departments of

$T$ Valdimarsson

G Toss

M Ström

and Preventive and

Community Medicine

O Löfman

Faculty of Health

Sciences, University

Hospital of Linköping,

Sweden

Correspondence to:

Dr T Valdimarsson,

Department of Interna

Medicine, Faculty of Health

Sciences, University Hospital

of Linköping, 58185

Linköping, Sweden

Accepted for publication

7 September 1995
TABLE I BMD at diagnosis in different groups, median $Z$ score $(I Q R)$

\begin{tabular}{|c|c|c|c|c|c|c|c|}
\hline No & $\begin{array}{l}\text { Median } \\
\text { age }\end{array}$ & Forearm & $p$ Value & Spine & p Value & Neck & $p$ Value \\
\hline All patients 63 & $53 \cdot 5$ & $\begin{array}{l}-0.91 \\
(-1.90 /-0.22)\end{array}$ & $\star \star \star$ & $\begin{array}{l}-0.63 \\
(-1.50 /+0.06)\end{array}$ & $\star \star \star$ & $\begin{array}{l}-0.54 \\
(1.27 /+0.37)\end{array}$ & $\star \star \star$ \\
\hline$\leqslant 25$ years 8 & $21 \cdot 8$ & $\begin{array}{l}-0.16 \\
(-1.45 /+0.59)\end{array}$ & NS & $\begin{array}{l}-0.31 \\
(-0.58 /+0.70)\end{array}$ & NS & $\begin{array}{l}+0.76 \\
(-0.27 /+1 \cdot 11)\end{array}$ & NS \\
\hline$>25$ years 55 & $55 \cdot 2$ & $\begin{array}{l}-1.14 \\
(-1.94 /-0.31)\end{array}$ & $\star \star \star$ & $\begin{array}{l}-0.78 \\
(-1.53 /-0.11)\end{array}$ & $\star \star \star$ & $\begin{array}{l}-0.81 \\
(-1.30 /-0.17)\end{array}$ & $\star \star \star$ \\
\hline$\geqslant 65$ years 14 & $70 \cdot 3$ & $\begin{array}{l}-1.24 \\
(-1.91 /-0.67)\end{array}$ & $\star \star$ & $\begin{array}{l}-1.32 \\
(-1.49 /-0.62)\end{array}$ & $\star \star$ & $\begin{array}{l}-0.82 \\
(-1.36 /-0.46)\end{array}$ & $\star \star$ \\
\hline All women 35 & $49 \cdot 3$ & $\begin{array}{l}-0.56 \\
(-1.73 /-0.22)\end{array}$ & $\star \star$ & $\begin{array}{l}-0.57 \\
(-1.35 /+0.23)\end{array}$ & $\star$ & $\begin{array}{l}-0.48 \\
(-1.21 /+0.38)\end{array}$ & * \\
\hline All men 28 & $55 \cdot 2$ & $\begin{array}{l}-1.23 \\
(-2 \cdot 13 /-0.33)\end{array}$ & $\star \star \star \star$ & $\begin{array}{l}-0.78 \\
(-1.54 /-0.37)\end{array}$ & $\star \star \star$ & $\begin{array}{l}-0.95 \\
(-1.44 /-0.17)\end{array}$ & $\star \star$ \\
\hline
\end{tabular}

${ }^{\star} \mathrm{p}<0.05 ;{ }^{\star \star} \mathrm{p}<0.01 ;{ }^{\star \star \star} \mathrm{p}<0.001$. 


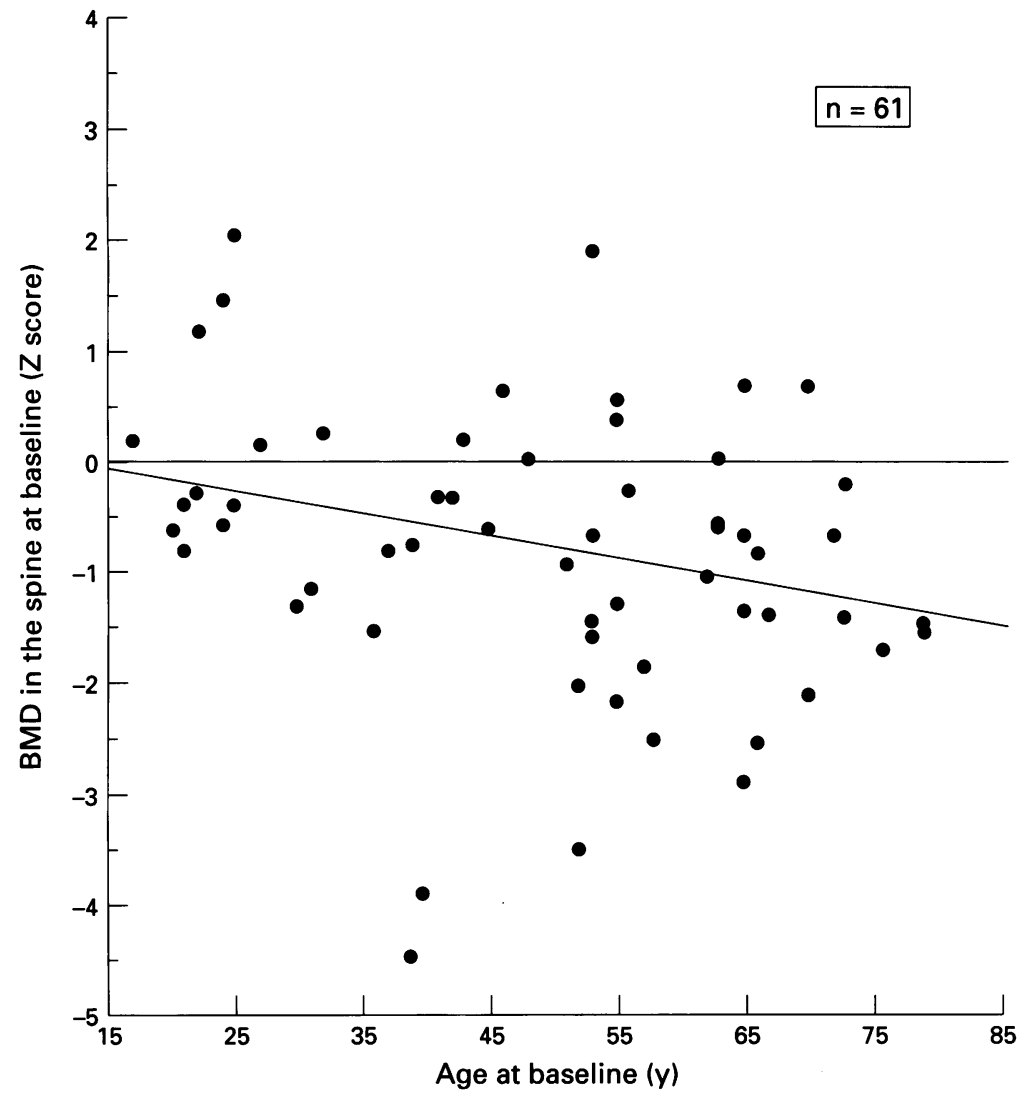

Figure 1: Bone mineral density ( $Z$ score) in the lumbar spine $\mathrm{v}$ age in patients with untreated coeliac disease. Zero line corresponds to the age and sex specific normal mean.

were given oral supplementation with calcium (calcium carbonate $250 \mathrm{mg}$ thrice daily) for 3-12 months. Five of these 13 patients who also had low 25 hydroxy-vitamin D (25-OHD3) $(\leqslant 35 \mathrm{nmol} / \mathrm{l})$ were given oral supplementation with vitamin $\mathrm{D}(500$ units/d) for $6-12$ months.

For each patient we selected 25 controls, matched for sex, age ( \pm 4 years) and menopausal state. The control group consisted of 680 subjects randomly selected from the population registry and found to be healthy at examination.

\section{Study design}

Forearm BMD was measured by single photon absorptiometry using a Möllsgård Nuclear Data 1100 instrument. ${ }^{13} \mathrm{BMD}$ in the spine and hip was measured by dual energy $x$ ray absorptiometry using a Hologic QDR 1000 instrument. ${ }^{14}$ By measuring patients and healthy subjects twice within a two week interval we found a precision of $1.0 \%$ in the spine and $1.3 \%$ in the femoral neck. Internal variation of the equipment was checked by daily calibration using a phantom. The repetitive precision in measuring a spine phantom was $0 \cdot 4 \%$. Blood tests were taken before and BMD was measured within three months of the start of dietary treatment. Intact serum parathyroid hormone (PTH) was determined using a two site immunoradiometric assay (Nichols Inst, San Juan Capistrano, CA). ${ }^{15}$ Serum concentrations of 25-OH-D3 was measured by immunoradiometric assay after purification on Sep-Pak C18 columns (Amersham, UK). ${ }^{16}$ Ionised serum calcium and alkaline phosphatase (ALP) were analysed by standard methods.

\section{Statistics}

$B M D$ was expressed as $Z$ score, defined as the deviation of the individual value from the mean value of each reference group expressed in units of the standard deviation. The Wilcoxon signed rank test and the Mann-Whitney U test were used when comparing paired and nonpaired data respectively. Correlation was evaluated by the Spearman rank test. Significance was set at the $5 \%$ level (two tailed).

\section{Ethics}

The study was approved by the Ethics Committee at the Faculty of Health Sciences, University of Linköping.

\section{Results}

\section{Untreated patients}

Age adjusted BMD was reduced at all sites in patients with untreated coeliac disease (Table I). Patients over the age of 25 and particularly those over the age of 65 had low BMD even when correlated for the expected decline in BMD with increasing age (Table I). Age adjusted $B M D$ in the lumbar spine was thus inversely corrected to age $(p<0.05 ; r=0.31)$ (Fig 1). The magnitude of the reduction did not differ between men and woman or between pre and postmenopausal women. Patients younger than the age of 25 had normal age adjusted $B M D$ and higher than those over the age of 25 ( $p<0.05$ all sites) (Table I). Patients who also had dermatitis herpetiformis had normal age adjusted BMD (Table II). Twenty two per cent of the untreated patients had severe $(Z$ score $<-2)$ and $24 \%$ had mild $(-2 \leqslant Z$ score $<-1)$ osteopenia ${ }^{\star}$ in the forearm and $15 \%$ and $23 \%$ in the spine respectively (Fig 2). In the 34 patients without symptoms of malabsorption (weight loss or diarrhoea) age adjusted $\mathrm{BMD}$ was significantly

*Osteopenia is used as an unspecific term for reduced BMD encompassing both osteoporosis and osteomalacia.

TABLE II BMD at diagnosis in patients with or without $D H$, median $Z$ score (IQR)

\begin{tabular}{|c|c|c|c|c|c|c|c|}
\hline No & $\begin{array}{l}\text { Median } \\
\text { age }\end{array}$ & Forearm & p Value & Spine & p Value & Neck & $p$ Value \\
\hline With DH 7 & $55 \cdot 2$ & $\begin{array}{l}-0.17 \\
(-1.82 /+0.53)\end{array}$ & NS & $\begin{array}{l}-0 \cdot 78 \\
(-1 \cdot 15 /+0 \cdot 65)\end{array}$ & NS & $\begin{array}{l}+0.36 \\
(0.83 /+0.60)\end{array}$ & NS \\
\hline Without DH 56 & $53 \cdot 3$ & $\begin{array}{l}-0.94 \\
(-1.88 /-0.28)\end{array}$ & $\star \star \star$ & $\begin{array}{l}-0.63 \\
(-1.50 /-0 \cdot 16)\end{array}$ & $\star \star \star$ & $\begin{array}{l}-0.74 \\
(-1.30 /-0.02)\end{array}$ & $\star \star \star$ \\
\hline
\end{tabular}

$\star \star \star \mathrm{p}<0.001$. 
TABLE III BMD at diagnosis in patients with or without symptoms of malabsorption (diarrhoea or weight loss), median $Z$ score $(I Q R)$

\begin{tabular}{|c|c|c|c|c|c|c|c|}
\hline No & $\begin{array}{l}\text { Median } \\
\text { age }\end{array}$ & Forearm & p Value & Spine & p Value & Neck & p Value \\
\hline $\begin{array}{l}\text { Symptoms of } \\
\text { malabsorption } 29\end{array}$ & 53.5 & $\begin{array}{l}-0.72 \\
(-1.72 /-0.28)\end{array}$ & $\star \star \star$ & $\begin{array}{l}-0.83 \\
(-1.51 /+0.12)\end{array}$ & $\star \star$ & $\begin{array}{l}-0.84 \\
(-1 \cdot 44 /-0.25)\end{array}$ & \\
\hline $\begin{array}{l}\text { No symptoms of } \\
\text { malabsorption } 34\end{array}$ & 53.3 & $\begin{array}{l}-1 \cdot 05 \\
(-2 \cdot 13 /-0 \cdot 10)\end{array}$ & $\star \star \star$ & $\begin{array}{l}-0.60 \\
(-1.31 /-0.11)\end{array}$ & $\star \star$ & $\begin{array}{l}-0.48 \\
(-1.07 /+0.39)\end{array}$ & $P=0.054$ \\
\hline
\end{tabular}

${ }^{\star \star} \mathrm{p}<0.01 ;{ }^{\star \star \star} \mathrm{p}<0.001$

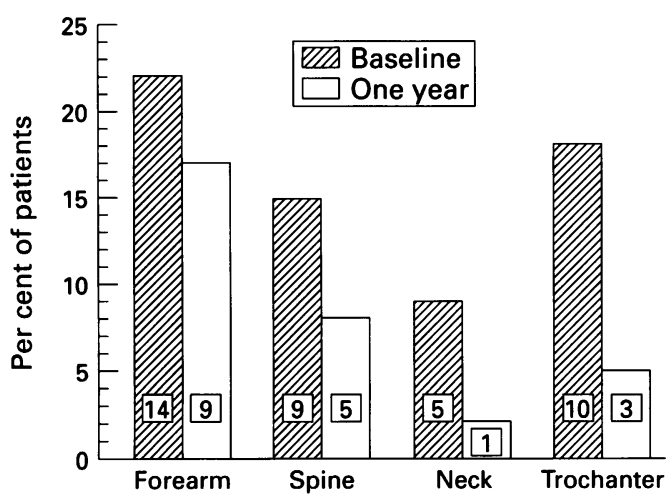

Figure 2: Per cent of patients with severe osteopenia ( $Z$ score <-2) before and after one year of a gluten free diet. Numbers of patients within bars.

reduced and as low as in the 29 patients with these symptoms (Table III). Table IV gives the occurrence of abnormalities in blood biochemistry. Age adjusted BMD in the spine was positively correlated to serum 25-OH-D3 ( $<<0.05 ; \mathrm{r}=0.32) \quad($ Fig 3$)$ and negatively correlated to serum ALP $(p<0.01$; $r=0.42)$ and PTH $(p<0.01 ; r=0.43)$. Similar correlation was found for the age adjusted $\mathrm{BMD}$ in the forearm, femoral neck, and trochanter.

After one year taking a gluten free diet

BMD increased at all sites during the first year of dietary recommendation (Table $\mathrm{V}$ and Fig 4). The increase was greatest in the spine and smallest in the distal forearm. After one year taking a gluten free diet the per cent of patients who had severe $(Z$ score $<-2)$ osteopenia had decreased considerable (Fig 2). Patients with dermatitis herpetiformis did not increase their BMD. Patients without symptoms of malabsorption increased their bone mass as much as the group with these symptoms. The increase of BMD in the group of patients over the age of 65 was as great as in young patients (Fig 5). After one year the BMD was still reduced at all sites $(\mathrm{p}<0.05)$.

The increase of lumbar and femoral BMD was greater in the group of 13 patients who had been given calcium or vitamin $\mathrm{D}$ supplementation but these patients also had lower BMD before dietary treatment. When excluding these 13 patients from the calculations, the $\mathrm{BMD}$ in the other 50 patients still was reduced before treatment and increased in the neck

TABLE IV Per cent of patients with abnormal laboratory data

\begin{tabular}{lllll}
\hline & $\begin{array}{l}25-\mathrm{OH}-\mathrm{D3} \\
(<35 \mathrm{nmol} /)\end{array}$ & $\begin{array}{l}P T H \\
(>65 \mathrm{ng} / \mathrm{l})\end{array}$ & $\begin{array}{l}\text { ALP } \\
(>4 \cdot 6 \mu \mathrm{kat} /)\end{array}$ & $\begin{array}{l}\text { Calcium } \\
(<1 \cdot 18 \mathrm{mmol} /)\end{array}$ \\
\hline Untreated & 8 & 27 & 23 & 18 \\
After one year & 0 & 12 & 11 & 0 \\
\hline
\end{tabular}

$(p<0.01)$ and spine $(p<0.001)$ during the first year of a gluten free diet.

Table IV shows that the occurrence of biochemical abnormalities was considerably reduced after one year. The increase of BMD in the spine was positively correlated to initial ALP $(\mathrm{p}<0.01 ; r=0.38)$ and PTH $(\mathrm{p}<0.001$; $r=0 \cdot 49)$. Similar correlation was seen for the femoral neck and trochanter.

\section{Discussion}

We found untreated coeliac disease to be strongly associated with low bone mineral density. This is in agreement with previous studies. ${ }^{8-10} 17-19$ In our study $22 \%$ of the patients had $\mathrm{Z}$ score below -2 in the forearm and $18 \%$ in the trochanter. In a prospective study the risk for fragility fracture of the hip was shown to be increased $4-5$ times at a $Z$ score -2.20

Age adjusted BMD was more severely reduced in the higher ages. While subjects in their third decade had a normal $Z$ score, those in the seventh or eight decades had a median $\mathrm{Z}$ score of -1.24 in the forearm and -1.32 in the spine, corresponding to approximately $80 \%$ of normal mean for age. A positive correlation between age and degree of osteopenia was also reported by Molteni et al. ${ }^{9} \mathrm{~A}$ longer duration of the disease before diagnosis, higher propensity for vitamin $\mathrm{D}$ deficiency or low calcium intake in the older subjects might explain this correlation.

Clinical presentation of coeliac disease may be very subtle. Of particular clinical interest is our finding that subjects without diarrhoea or weight loss had osteopenia of the same degree as subjects with these symptoms. Molteni et al ${ }^{9}$ similarly found no correlation between osteopenia and severity of symptoms. Mazure et al found reduced BMD in asymptomatic relatives to patients with coeliac disease but not as much as in the symptomatic untreated patients. ${ }^{10}$ In our opinion, screening for coeliac disease is indicated in all adult patients with osteoporosis or osteopenia. Indeed, in a Swedish study on osteoporotic patients, the prevalence of coeliac disease was appoximately 10-fold higher than in the general population. ${ }^{7}$

Dermatitis herpetiformis with coeliac disease seems to be an entity separate from common coeliac disease. ${ }^{21}$ The seven patients with dermatitis herpetiformis included in our study had normal BMD and normal vitamin D and PTH status, although all had villous atrophy in the proximal small bowel of grade III or IV (Alexander's classification). ${ }^{12}$ Similar findings have been reported by Mellström 


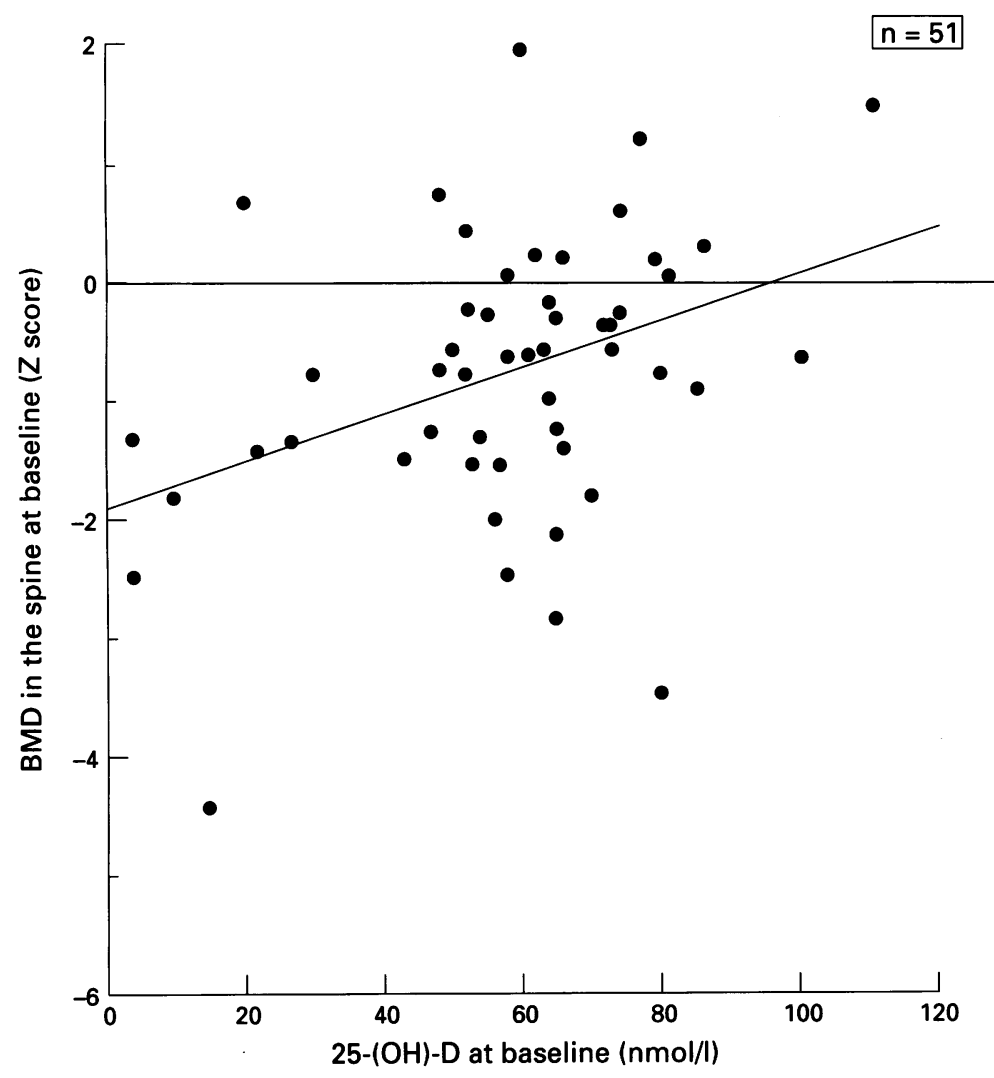

Figure 3: Serum 25-hydroxy-vitamin $D \mathrm{v}$ bone mineral density of the lumbar spine in patients with untreated coeliac disease.

TABLE V Change in BMD during one year in per cent of initial value $\left(\mathrm{g} / \mathrm{cm}^{2}\right)$, median $(I Q R)$

\begin{tabular}{lllllll}
\hline No & Forearm & $p$ Value & Spine & $p$ Value & Neck & $p$ Value \\
\hline All patients 63 & $1(-1 /+4)$ & $\star \star$ & $3(+1 /+7)$ & $\star \star \star$ & $2(-1 /+10)$ & $\star \star \star$ \\
$\leqslant 25$ years 8 & $2(+1 /+3)$ & $\star$ & $2(+1 /+3)$ & $\star$ & $0(-1 /+3)$ & NS \\
$>25$ years 55 & $1(-2 /+4)$ & $\star$ & $3(+1 /+8)$ & $\star \star \star$ & $3(-1 /+11)$ & $\star \star \star$ \\
$\geqslant 65$ years 14 & $0(-4 /+5)$ & NS & $5(+2 /+16)$ & $\star \star$ & $8(-1 /+11)$ & $\star$ \\
All women 35 & $1(0 /+5)$ & $\star$ & $2(+1 /+4)$ & $\star \star \star$ & $1(-1 /+4)$ & $\star$ \\
All men 28 & $1(-2 /+3)$ & NS & $4(0 /+13)$ & $\star \star \star$ & $6(+1 /+12)$ & $\star \star \star$ \\
\hline
\end{tabular}

${ }^{\star \star} \mathrm{p}<0.05 ;{ }^{\star \star} \mathrm{p}<0.01 ;{ }^{\star \star \star} \mathrm{p}<0.001$
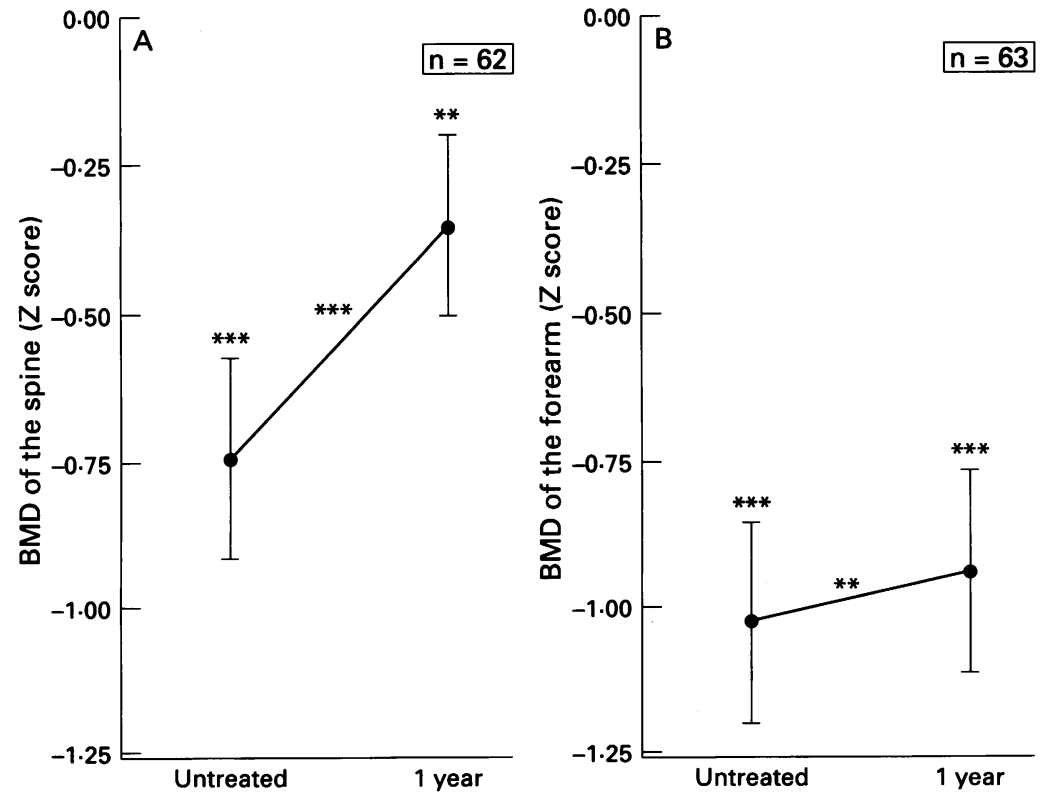

Figure 4: Change in bone mineral density ( $Z$ score, mean and SEM) of the spine $(A)$ and forearm (B) during one year of dietary treatment. ${ }^{\star \star} p<0.01 ;{ }^{\star *} p<0.001$. et $a^{22}$ who found normal BMD in 12 patients with dermatitis herpetiformis.

The lowest BMD was found in subjects with vitamin $\mathrm{D}$ deficiency and secondary hyperparathyroidism. Some of these subjects might have had osteomalacia, but bone biopsies were not performed to confirm this. Osteomalacia caused by coeliac disease has been reported in a few studies 21723 and may occur in the absence of steatorrhea. ${ }^{3}$ However, BMD was reduced and serum PTH was also increased in some patients with normal serum concentrations of 25-OH-D3. This suggests that calcium malabsorption may also result from mechanisms other than vitamin $\mathrm{D}$ deficiency; for example, a reduced active absorptive surface area, as previously suggested by $\mathrm{Ng}^{24}$

In cross sectional studies causal relations must be interpreted with caution. In this prospective study, BMD increased considerally in all sites after one year taking a gluten free diet. These findings, together with our previous findings of normal BMD in subjects who have adhered to a strict gluten free diet for more than four years, ${ }^{11}$ suggest that osteopenia in coeliac disease is rapidly reversible. This is in agreement with the normal BMD reported in young patients treated with gluten free diet for more than 10 years ${ }^{9}$ and the higher increment of $\mathrm{BMD}$ in 14 treated children than in controls. ${ }^{25}$ One prospective study on BMD in adult coeliac disease did not find an increase in BMD after one year of a gluten free diet. ${ }^{8} \mathrm{McF}$ arlane et al recently reported serial BMD measurements over one year on 55 adult patients with treated coeliac disease with a mean time spent taking a gluten free diet of 4.25 years (range 0.4-10). They found osteopenia ( $Z$ score $\leqslant-1$ ) in $47 \%$ of the patients but there was no significant correlation between the duration of dietary recommendation and BMD. The authors did not report on the dietary compliance or residual histopathological changes. During the follow up year BMD improved and the largest gain was found in patients with most recently diagnosed coeliac disease. ${ }^{23}$ Ciacci et al found BMD 'below normal' in 25 of 45 untreated patients and after one year of dietary treatment BMD had 'recovered' in 10 of 25 , all under the age of $25 .{ }^{26}$ In contrast with our findings, Ciacci concluded that recovery of low BMD seemed probable only if a gluten free diet was started before the age of 25 .

The reported absence of improvement of BMD during the first year of a gluten free diet ${ }^{8}$ and the low BMD in treated patients ${ }^{10} 2327-28$ are in contrast with our findings. The degree of osteopenia found in these studies might possibly result from poor dietary compliance. Whether oral calcium or vitamin D supplements were given in these contrasting studies is not clear. Our patients adhered to a strictly gluten free diet with the exception of eight patients who kept a gluten reduced diet. In a previous cross sectional study we found that subjects with incomplete dietary treatment for a median time of nine years still had low BMD. ${ }^{11}$ In this study, 13 patients who had low serum ionised calcium values or a low calcium 


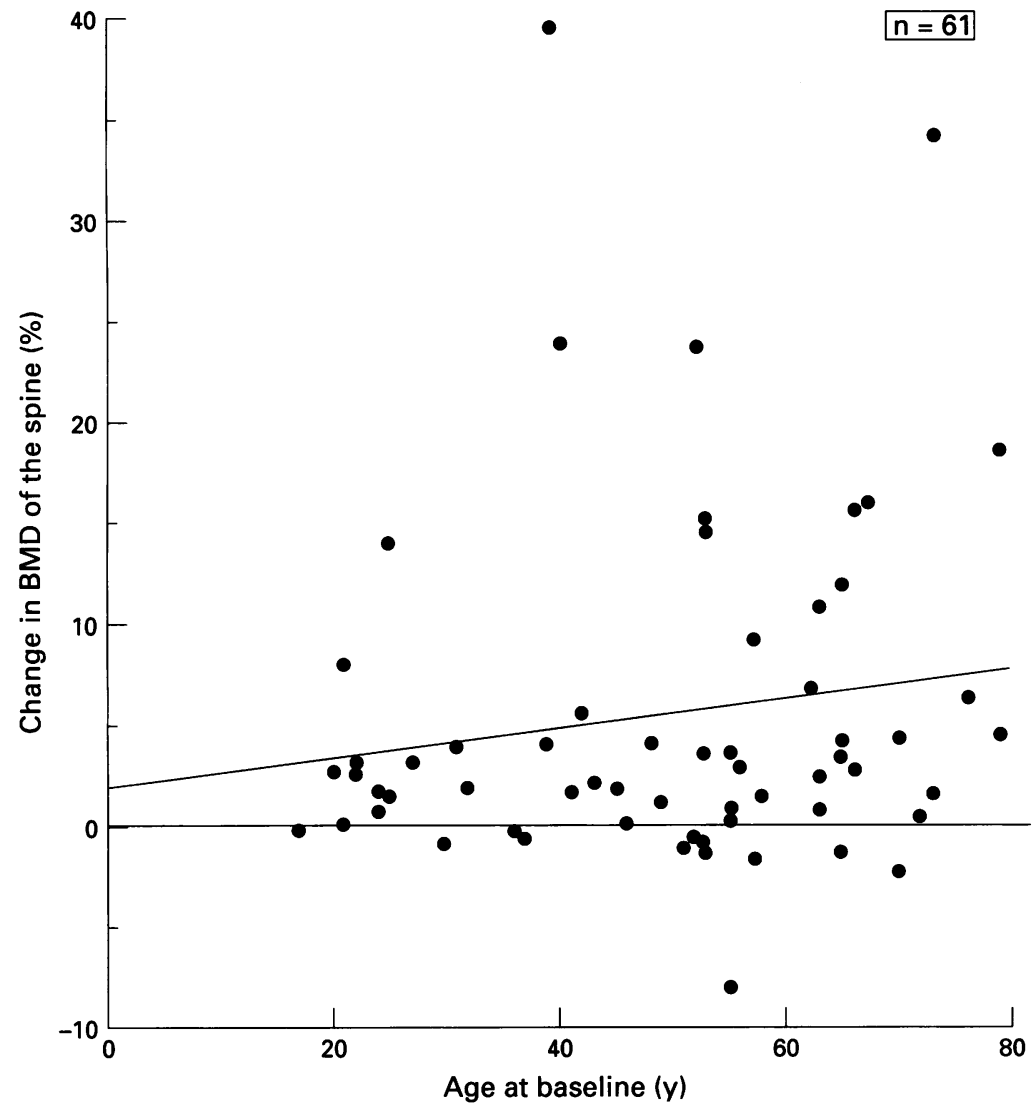

Figure 5: Change (\%) in bone mineral density ( $Z$ score) of the spine during one year treatment with a gluten free diet, given $\mathrm{v}$ age.

intake were given calcium supplements, and five of them who also had a 25-hydroxyvitamin D concentration under $35 \mathrm{nmol} / \mathrm{l}$ were given vitamin D supplements as well. When excluding these 13 patients from the calculations, our results were unchanged except in the forearm, where the increase was no longer significant $(p=0.093)$. Mora et $a^{25}$ did not find any effect of oral 25-OH-D3 on BMD. The value of calcium or vitamin D supplementation has not been studied prospectively. Our 13 patients who were given supplementation increased their BMD more than the other 50 patients. This could also be caused by an initially secondary hyperparathyroidism correcting during dietary treatment.

Twelve of our 63 patients showed a remarkable increase in BMD of more than $10 \%$ in one year. Part of this improvement might result from a reduction of the large remodelling space as seen in hyperparathyroidism. Before treatment, nine of 12 patients had secondary hyperparathyroidism. Seven patients with normal PTH status also increased their BMD more than $5 \%$ during the first year pointing to other bone formation mechanisms.

The large increment of $\mathrm{BMD}$ in subjects over the age of 65 is of great clinical importance. The 5\% increment of lumbar BMD and $8 \%$ increment of BMD of the neck in only one year is more than what can usually be accomplished by pharmacological treatment of osteoporosis today. ${ }^{29}$ As might be expected from pharmacological treatment studies, ${ }^{29}$ the increment of BMD was most rapid in trabecular bone (such as spine and trochanter) and less rapid, although significant, in the cortical bone of the distal forearm, which has a lower bone turnover rate.

Patients who had adhered to a strict gluten free diet and normalised their small bowel mucosa for at least four years had normal mean BMD. ${ }^{11}$ In this prospective study the bone mass increased rapidly during the first year of dietary treatment but was still reduced. To clarify whether the osteopenia in coeliac disease is completely reversible we intend to continue this follow up in consecutive patients.

Coeliac disease is associated with pronounced osteopenia and a gluten free diet results in a rapid increase of BMD. This is seen even in patients with minor or no gastrointestinal symptoms and in subjects over the age of 65. Diagnosis and treatment is therefore important in all patients with coeliac disease.

1 Salvesen HA, Böe J. Osteomalacia in sprue. Acta Med Scand 1953; 1466: 290-9.

2 Juergens JL, Scholz DA, Wollaeger EE. Severe osteomalacia associated with occult steatorrhea due to nontropical sprue. Arch Intern Med 1956; 98: 744

3 Moss AJ, Waterhouse C, Terry R. Gluten sensitive enteropathy with osteomalacia but without steatorrhea. $N$ Engl f Med 1965; 272: 825-30

4 Melvin KEW, Hepner GW, Bordier P, Neale G, Joplin GF. Calcium metabolism and bone pathology in adult coeliac disease. $Q \mathcal{F}$ Med 1970; 39: 83-113.

5 Hepner GW, Jowsey J, Arnaud C, Gordon S, Black J, Roginsky M, et al. Osteomalacia and celiac disease. Response to 25-hydroxy vitamin D. Am f Med 1978; 65: 1015-20.

6 Cooke WT, Holmes GKT. Clinical presentation. In: Cooke WT, Holmes GKT, eds. Coeliac disease. Edinburgh: Churchill-Livingstone, 1984; 90-5.

7 Lindh E, Ljunghall S, Larsson K, Lavö B. Screening for antibodies against gliadin in patients with osteoporosis. fInt Med 1992 231: 403-6.

8 Caraceni MP, Molteni N, Bardella MT, Ortolani S, Nogara A, Bianchi PA. Bone and mineral metabolism in adul celiac disease. Am $\mathcal{F}$ Gastroenterol 1988; 3: 274-7.

9 Molteni N, Caraceni MP, Bardella MT, Ortolani S, Gandolini GG, Bianchi PA. Bone mineral density in adult celiac patients and the effect of gluten free diet from childhood. Am $\mathcal{f}$ Gastroenterol 1990; 1: 51-3.

10 Mazure R, Vazquez H, Gonzalez D, Mautalen C, Pedreira $\mathrm{S}$, Boerr $\mathrm{L}$, et al. Bone mineral affection in asymptomatic adult patients with celiac disease. Am $\mathcal{F}$ Gastroenterol 1994; 89: $2130-4$.

11 Valdimarsson T, Toss G, Ross I, Löfman O, Ström $M$. Bone mineral density in coeliac disease. Scand $\dot{f}$ Gastroenterol 1994; 29: 457-61.

12 Alexander JOD. Dermatitis Herpetiformis. In: Rook A, ed. Major problems in dermatology: Vol IV. London: WB Saunders, 1975: 236-80.

13 Christiansen C, Rödbro P, Jensen H. Bone mineral content in the forearm measured by photon absorbiometry. Principles and reliability. Scand $\mathcal{F}$ Clin Lab Invest 1975; 35: 323-30.

14 Cullum ID, Ell PJ, Ryder JP. X-ray dual-photon absorbtiometry: a new method for the measurement of bone density. $B r \dot{F}$ Radiol 1989; 62: 587-92.

15 Nussbaum SR, Zahradnik RJ, Lavigne JR, Brennan GL, Nozava-Ung K, Kim LY, et al. Highly sensitive two-site immunoradiometric assay of parathyrin and its clinical utility in evaluating patients with hypercalcemia. Clin utility in evaluating patier
Chem 1987; 33: 1364-7

16 Clarke AD, Rowbury CS. Removal of lipids before liquid chromatography of vitamin D in serum. Clin Chem 1985; 31: $657-8$.

17 Janatuinen E, Alhava E, Arnala I, Julkunen R, Kosma $\mathrm{VM}$, Kröger $\mathrm{H}$, et al. Bone density and histomorphometry in adult coeliac disease. Gastroenterology 1992; 102: A216.

18 Corazza GR, Di Sario A, Cecchetti L, Tarossi C, Jorizzo R, Gasbarrini G. Prevalence, degree and pathophysiology of bone loss in adult coeliac disease. Gut 1994; 35 (suppl 5): S4.

19 McFarline X, Bhalla A, Morgan L, Reeves D, Robertson DAF. Osteoporosis: a frequent finding in treated coeliac disease. Gut 1992; 33 (suppl 2): S48.

20 Cummings SR, Black DM, Nevitt MC, Browner W, Cauley $\mathrm{J}$, Ensrud $\mathrm{K}$, et al. Bone density at various sites for predic$\mathrm{J}$, Ensrud K, et al. Bone density at various sites
tion of hip fractures. Lancet 1993; 341: 72-5.

21 Cooke WT, Holmes GKT. Clinical presentation. In: Cooke WT, Holmes GKT, eds. Coeliac disease. Edinburgh: Churchill-Livingstone, 1984: 215-6.

22 Mellstöm D, Johansson C, Kilander A, Lindstedt G Mobacen $\mathrm{H}$. Osteoporosis är ovanligt hos patienter med dermatitis herpetiformis [Abstract]. Svenska läkarsällskapets handlingar, Hygiea 1992; 101: 162.

23 McFarline XA, Bhalla AK, Reeves DE, Morgan LM Robertson DAF. Osteoporosis in treated adult coeliac disease. Gut 1995; 36: 710-4. 
$24 \mathrm{Ng}$ DPK, Stone M, Hosking DJ, Long RG. Calcium malabsorption in celiac sprue is not the result of vitamin D deficiency. Gastroenterology 1992; 102: A229.

25 Mora S, Weber G, Barera G, Bellini A, Pasolini D, Prinster C, et al. Effect of gluten-free diet on bone mineral content in growing patients with celiac disease. Am $\mathrm{f}$ Clin Nutr 1993; 57: 224-8.

26 Ciacci C, Maurelli L, Klain M, Sabbatini F, Salvatore M, Mazzacca G, Calcium homeostasis and adult celiac disease: age related recovery of bone mineral density after gluten-free diet. Gut 1994; 35: A197.
27 Bodé S, Hassager C, Gudmand-Höyer E, Christiansen C. Body composition and calcium metabolism in adul treated coeliac disease. Gut 1991; 32: 1342-5.

28 Butcher GP, Banks LM, Walters JRF. Reduced bone mineral density in coeliac disease - the need for bone densitometry estimations. Gut 1992; 33 (suppl 2): S54.

29 Storm T, Thamsborg G, Steiniche T, Genant H, HelmerSörensen $O$. Effect of intermittent cyclical etidronate therapy on bone mass and fracture rate in women with postmenopausal osteoporosis. $N$ Engl $\mathcal{F}$ Med 1990; 322: 